\title{
Studies on the enforcement of the Low Carbon City Promotion Act and a case example of Low Carbon City Development Plan in Omihachiman City
}

\author{
Y. Suzuki ${ }^{1}$, F. Kakei $^{1}$, C. Yamamoto ${ }^{1}$, M. Sawaki ${ }^{2}$, \\ R. Matsunaka ${ }^{3} \&$ Y. Moritsu ${ }^{4}$ \\ ${ }^{1}$ NIKKEN SEKKEI Research Institute, Japan \\ ${ }^{2}$ Osaka University, Japan \\ ${ }^{3}$ Kyoto University, Japan \\ ${ }^{4}$ City of Omihachiman, Japan
}

\begin{abstract}
The Low Carbon City Promotion Act was enacted in December 2012 to address the issues that Japan has been facing, such as global warming, declining population, aging society and local government financial deterioration. This paper reviews the background and intents of the Low Carbon City Promotion Act. In addition, as the latest advanced case example, Low Carbon City Development Plan for Omihachiman City that has been formulated in accordance with the Act is studied in this paper. Omihachiman is a city with traditional culture and unique history. This study found that it contributes to realize a low-carbon and sustainable city by designing the plan which covers the whole city boundary of Omihachiman City and defining the basic policies and measures that make the urban structure more compact and the urban functions centralized. The low-carbon measures proposed in this plan include promotion of public transportation use, conservation of natural environment and greening, renewable energy use, efficient use of fossil fuel, reduction of $\mathrm{CO}_{2}$ emissions from buildings and vehicle emissions control. By approaching these measures, this study defined the effects of increases in floor area and population density surrounding the transport nodes and moreover reduction in $\mathrm{CO}_{2}$ emissions in the entire city.

Keywords: planning low-carbon city development, sustainable city, centralized urban structure, transport node, simulation, analysis on $\mathrm{CO}_{2}$ reduction effects.
\end{abstract}




\section{Introduction}

Japan emitted 1.334 billion tons $\mathrm{CO}_{2}$ during April 2012 to March 2013. It was a $2.8 \%$ increase from the previous fiscal year. And it is $6.5 \%$ higher than the 1990 benchmark used by the Kyoto Protocol [1]. More than 50\% of total amount of emissions are emitted from the civilian sector such as households, commercial and transportation which are all related to urban activities. Significantly, in recent years, the amount of emissions from households and commercial sector has been continuingly increased.

If the $\mathrm{CO}_{2}$ emissions from energy consumption in these 3 sectors are related to the socioeconomic activities in a city, most of the emissions are emitted from urban planning area. It is essential to cope with this matter in urban and community planning. Progressing toward reducing $\mathrm{CO}_{2}$ in urban planning area is a big challenge in regard to global environmental issues, and it has a big role in a society. Also, its importance of low-carbon urban and community structure formation and socioeconomic system design has been stated in Kyoto Protocol Target Achievement Plan.

Moreover, Japan will be an aged society earlier than other developed countries. Population in Japan tends to decline after the peak in 2004. As of October 2013, total population was 127.3 million, $25.1 \%$ of the population was over 65 years with 3.19 million [2]. This number is significantly high level compared to other developed region with average of 15 to $20 \%$.

A sustainable and vital urban and community development for people as well as dealing with global warming is the social requirement in recent Japan.

\section{Brief overview of the Low Carbon City Promotion Act}

The Low Carbon City Promotion Act was enacted in December 2012 to address the issues mentioned at the introduction. This paper reviews the background and intents of the Low Carbon City Promotion Act.

\subsection{The direction of urban planning for the next decades}

Japan has been forced to cope with the issues surrounding sustainable cities and urban development. The successful running and developing cities in which elderly people live independently and households with children raise their children comfortably without anxiety are required. However, since local government financial deterioration might grow increasingly severe, it brings a shortage of administrative service cost for upgrading and managing urban infrastructure stocks and social welfare in near the future. Whereby, in Japan, it is strongly required to be steadily carrying out sustainable and lively urban and community development for the future.

For dealing with these issues and meeting human needs, and as a direction of urban planning for the next decades, implementing compact cities is an effective way. The urban functions needed in our daily life are centralized nearby residential area. Also, people can access to these urban functions like public facilities by public transportation instead of dependent on private car use. 
Financial expenditure

- Public investment efficiency

- Saving in the cost related to social welfare

Sustainable growth using limited resources

Global environment

- Green innovation

- Reduction of $\mathrm{CO} 2$ emissions
Comfortable environment for elderly people and households with children

- Promotion of health

- Participation of elderly people and woman

Figure 1: Idea of sustainable urban development.
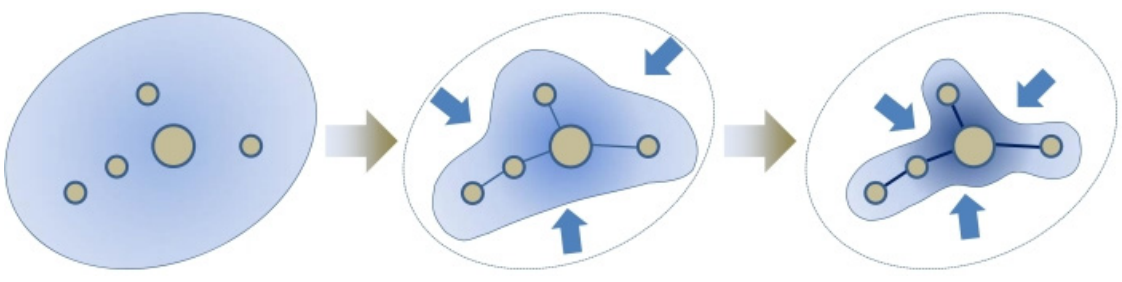

Figure 2: Image of centralizing urban functions.

\subsection{The Low Carbon City Promotion Act}

Against the backdrop of environmental, social and financial circumstances, the Low Carbon City Promotion Act was enacted as the first step. This Act leads local governments to progress toward their achievement of compact urban development in coordination with citizens and private sectors from the view point of environmental friendly life style and aging society with fewer children [3].

In accordance with the Act, local governments are in a position to put forward low-carbon city development and promote investment from private sector by formulating a Low Carbon City Development Plan. It is expected to formulate the plan which enhances areal characteristics.

Low Carbon City Development Plan aims at promoting low-carbon city development measures within urbanization promotion area. The measure covers centralization of urban functions, promotion of public transportation use, conservation of green space, promotion of greening, and reduction of $\mathrm{CO}_{2}$ emitted from buildings. The plan states (1) planning area, (2) objective, (3) measures for achieving objective, (4) process of evaluation, and (5) duration and schedule. National government provides financial assistance to the local government who formulates the plan, table 1 . 
Table 1: Example of financial assistance.

\begin{tabular}{|l|c|}
\hline & $\begin{array}{c}\text { Cost sharing ratio of } \\
\text { national expenditure }\end{array}$ \\
\hline Formulation of Low Carbon City Development Plan & $1 / 2$ \\
\hline Development project related to urban centralization & $1 / 3$ \\
\hline Development project of pedestrian road and parking lot & $4 / 10,5.5 / 10,1 / 3,1 / 2$ \\
\hline Improvement of bus services and development project of LRT & $1 / 2,1 / 3$ \\
\hline Reduction of $\mathrm{CO}_{2}$ emitted from buildings & $1 / 2$ \\
\hline
\end{tabular}

\section{Low Carbon City Development Plan for Omihachiman City}

Low Carbon City Development Plan for Omihachiman City has been formulated in accordance with the Low Carbon City Promotion Act $[4,5]$. This plan covers the whole city boundary and defines the basic policies and measures that make the urban structure more compact and the urban functions centralized. Targeting entire city in the Plan is the first attempt in regard to meeting of low-carbon and sustainable development goals. In this paper, this plan is studied as the latest advanced case example.

\subsection{Basic information of Omihachiman city}

Omihachiman city, the area of $101.27 \mathrm{sq} \mathrm{km}$ sites at the foot of Mt. Hachiman on the south-eastern shore of Lake Biwa, is located in the centre of Shiga prefecture, Japan. Omihachiman city had been developed as a castle and commercial town in the end of 16th century. In an old part of the city, where former merchant residents and a canal are preserved, is designated as a preservation district for groups of traditional buildings and an important cultural landscape.

According to the survey on the basic register of residents in 2013 [8], it has a population of 82,292 and households of 31,738 . The population is still increasing slightly, and increasing in number of households shows the trend toward the nuclear family. Looking at the population's age, declining birth rate and a growing proportion of elderly people are continuingly appeared recent years.

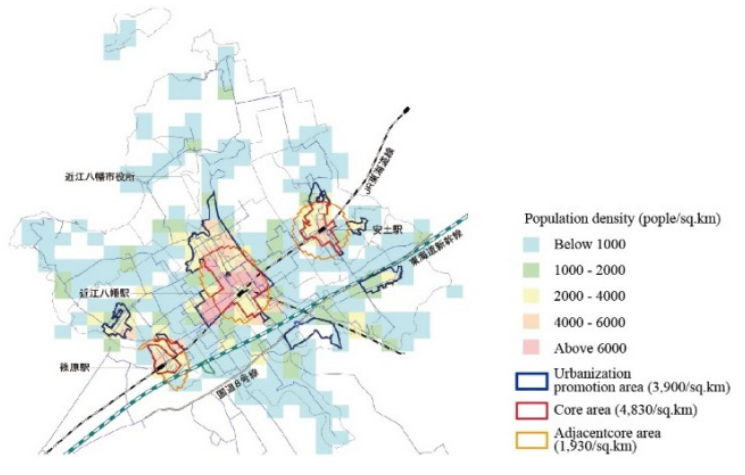

Figure 3: Population density. 
In Omihachiman city, half of the land is used for agricultural use, and urbanized area is formed quite compact. According to the survey in 2005, the area of densely inhabited district (DID) is $5.63 \mathrm{sq} \mathrm{km}$ containing population of 33,699 . The DID area has not been expanded much since 2005. However, on the fringe and outer area, development have been continuingly increasing, urbanization pressure tends to move out from central area to outward.

\subsection{Issues and directions of urban development in Omihachiman}

The Low Carbon City Development Plan for Omihachiman City defines the directions of urban development by clarifying the issues to realize low-carbon city, fig. 4. Main issues are that even the urbanized area is quite compact, housings are spreading over a wide area, and development potential is still increasing on fringe of suburban area, fig. 5. Public facilities are spreading out so that people needs to move place to place, fig. 6. Also, people are dependent on private cars to maintain their mobility, fig. 7. As shown in fig. $8, \mathrm{CO}_{2}$ is emitted entire city. It is essential to improve efficient energy use. In this circumstance, the plan defines directions of centralizing urban functions including residence and promoting public transportation use to reduce $\mathrm{CO}_{2}$ emissions.

\begin{tabular}{|c|c|}
\hline Issues & Directions \\
\hline Public facilities are spreading out. & Centralizing urban functions near the \\
\hline Housing are spreading over a wide & community in central of the city. \\
\hline area. & Promoting walkable urban development. \\
\hline People are depend on private car use. & Modal shift to lower environmental load \\
\hline $\begin{array}{l}\text { Control } \mathrm{CO}_{2} \text { emissions from } \\
\text { automobiles. }\end{array}$ & $\begin{array}{l}\text { means such as public transportation, } \\
\text { bicycle and eco car. }\end{array}$ \\
\hline $\begin{array}{l}\text { Existence of car users going neigh- } \\
\text { bouring city for work or shopping. }\end{array}$ & $\begin{array}{l}\text { Development of activity hub for work } \\
\text { and shopping in central of the city. }\end{array}$ \\
\hline $\begin{array}{l}\text { Reduction of } \mathrm{CO}_{2} \text { emissions from } \\
\text { buildings }\end{array}$ & $\begin{array}{l}\text { Use energy efficient way and promote } \\
\text { buildings rehabilitation to high energy } \\
\text { efficient buildings. }\end{array}$ \\
\hline Reusable energy use. & Introduction of new technologies. \\
\hline $\begin{array}{l}\text { Maintenance and conservation of } \\
\text { green space. }\end{array}$ & $\begin{array}{l}\text { Maintenance and conservation of exist- } \\
\text { ing green, park and farm, and greenery. }\end{array}$ \\
\hline
\end{tabular}

Figure 4: Issues and directions of urban development.

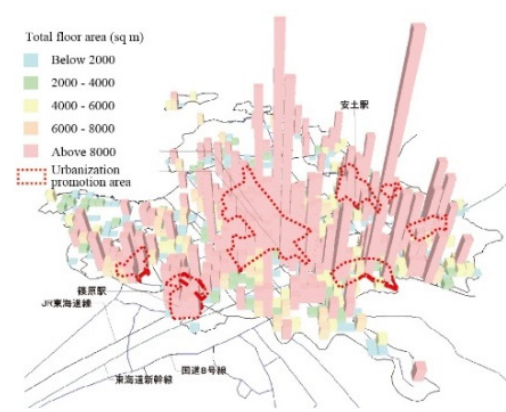

Figure 5: Total floor area.

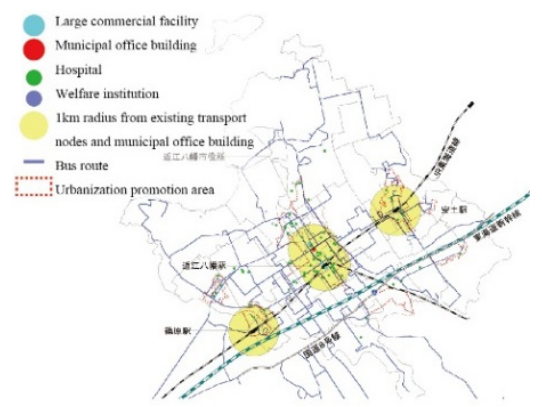

Figure 6: Public facility location map. 


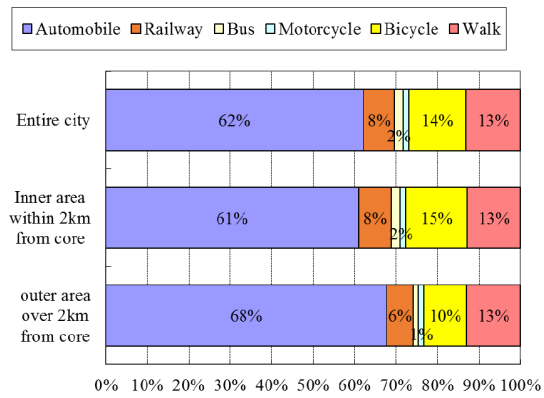

Figure 7: Modal split.

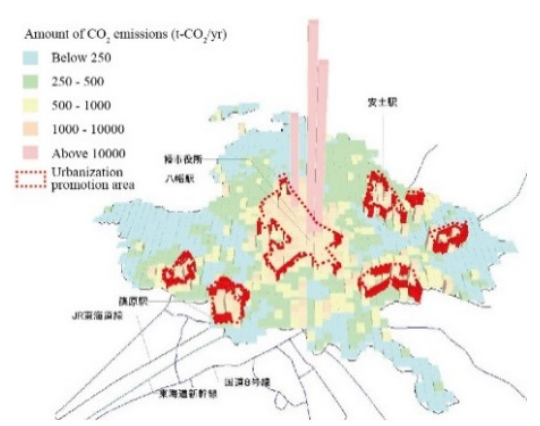

Figure 8: Amount of $\mathrm{CO}_{2}$ emissions.

\subsection{Scope of Low Carbon Development City Plan for Omihachiman City}

\subsubsection{Planning area and other designated areas}

This plan covers the whole city boundary, total area of 1,031 ha, planning area within urbanization promotion area and other areas are designated as follows, table 2.

Table 2: Designated area for each activity use.

\begin{tabular}{|c|c|c|}
\hline Name of area & Purpose & Designation \\
\hline $\begin{array}{c}\text { Core area } \\
\text { (524 ha) }\end{array}$ & $\begin{array}{l}\text { Centralizing urban } \\
\text { functions }\end{array}$ & $\begin{array}{l}\text { Area within a distance of } 1 \mathrm{~km} \text { radius from existing } \\
\text { transport nodes and is urbanization promotion area } \\
\text { defined in Urban Planning Act. These transportation } \\
\text { nodes include three train stations and a municipal office } \\
\text { building which is the hub of bus network. }\end{array}$ \\
\hline $\begin{array}{l}\text { Adjacent core } \\
\text { area (394 ha) }\end{array}$ & $\begin{array}{l}\text { Controlling } \\
\text { potential land use } \\
\text { demand }\end{array}$ & $\begin{array}{l}\text { Area within a distance of } 1 \mathrm{~km} \text { radius from existing } \\
\text { transport nodes and is urbanization control area defined in } \\
\text { Urban Planning Act. Leading land use of potential } \\
\text { demand for increasing population. }\end{array}$ \\
\hline $\begin{array}{l}\text { Natural and } \\
\text { reusable energy } \\
\text { area }(9 \text { ha })\end{array}$ & $\begin{array}{l}\text { Greening and } \\
\text { introduction of } \\
\text { reusable energy }\end{array}$ & $\begin{array}{l}\text { Area in which to conserve green space and promote } \\
\text { greening. Also to promote reusable energy use } \\
\text { intensively. }\end{array}$ \\
\hline
\end{tabular}

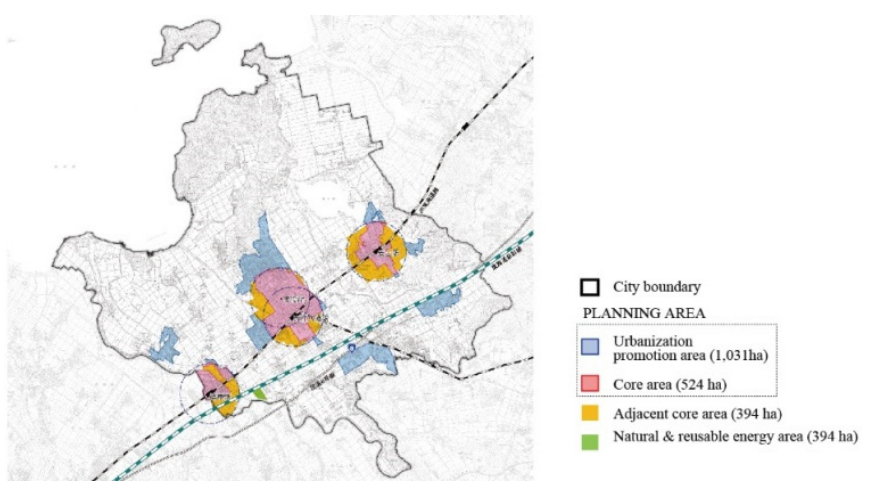

Figure 9: Planning area and other designated areas. 


\subsubsection{Planning objective and image of centralized urban form}

Objective of this plan is to develop low-carbon and sustainable city with creation of lively and vital communities. This plan is designed to create compact urban structure by centralizing urban functions in core areas and to improve residential environment for elderly people and households with children at the same time. These approaches are taken to reduce $\mathrm{CO}_{2}$ emissions and promote lively and vital communities in the core areas.

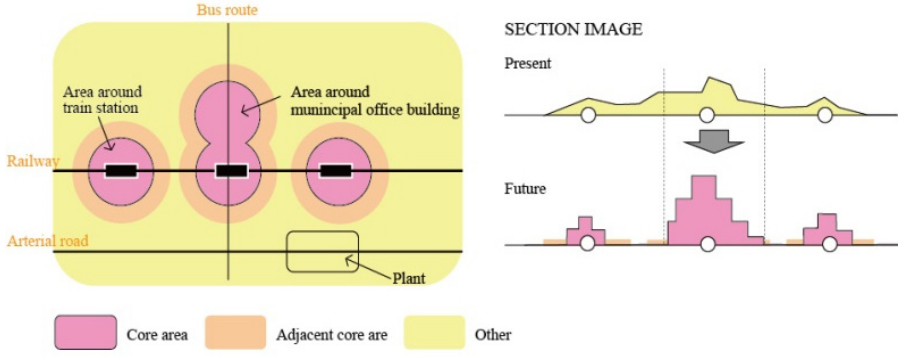

Figure 10: Image of centralization of urban structure.

\subsubsection{Directions and measures}

Based on the objective, by deliberate reallocation of public facilities, medical and welfare institution and other facilities like commerce within core areas, it contributes to raise the number of floor area and population density. At the centralization of urban functions within core areas, development is controlled properly as considering its landscape and environmental impact. Also, the measure of promotion of public transportation use, conservation of green space, promotion of greening, introduction of reusable energy use, efficient use of fossil fuel, and reduction of $\mathrm{CO}_{2}$ emitted from both buildings and vehicles are proposed in this plan.

\section{Case study of centralizing urban functions in Omihachiman city}

\subsection{Outline of case study}

Among these six basic policies of Low Carbon City Development Plan, centralizing urban functions is key to realize low-carbon city development. Therefore we chose the policy of urban functions centralization as a main topic to study in this chapter. Its effects based on case studies are described.

We prepared 5 patterns of urban centralization shown as table 4. As a shortterm case study, municipal office area where has ongoing redevelopment plan is selected. In middle and long-term, we prepared several urban centralization patterns which reflect general situation of Japanese cities. For instance, we consider centralization of residential functions as less-feasible scenario, since strong private right of house owners tends to prevent movement of their settlement in Japan. 
Moreover, we included the followings in urban centralization effects; effect of modal shift to public transportation and effect of building rehabilitation in core area.

Table 3: Basic policies and measures for realizing low-carbon city.

\begin{tabular}{|c|c|}
\hline Basic policies & Measures \\
\hline \multirow{2}{*}{$\begin{array}{l}\text { 1. Centralizing urban functions } \\
\text { Promotion to settle resident inner city by } \\
\text { placement of public facilities, medical and } \\
\text { welfare institution, commercial facilities } \\
\text { centralized. }\end{array}$} & (1) Placement of urban functions within core area. \\
\hline & $\begin{array}{l}\text { (2) Reallocation of old facilities from fringe to } \\
\text { core area. }\end{array}$ \\
\hline \multirow{5}{*}{$\begin{array}{l}\text { 2. Promotion of public transportation use } \\
\text { Promotion of walkable urban development by } \\
\text { building safe and attractive pedestrian roads, } \\
\text { and improving public transportation services. }\end{array}$} & (1) Building safe and attractive pedestrian roads. \\
\hline & (2) Preparation of convenient transit hub \\
\hline & (3) Improvement of bus services \\
\hline & (4) Preparation of bicycle lanes \\
\hline & (5) Introduction of community cycle \\
\hline \multirow{3}{*}{$\begin{array}{l}\text { 3. Conservation of green space and greenery } \\
\text { Conservation of existing green, and promote } \\
\text { greenery. }\end{array}$} & (1) Conservation of green space and park \\
\hline & (2) Promotion of greenery at public space \\
\hline & (3) Promotion of greenery at private property area \\
\hline \multirow{3}{*}{$\begin{array}{l}\text { 4. Introduction of reusable energy use and } \\
\text { efficient energy use } \\
\text { Introduction of reusable energy like PV and } \\
\text { efficient energy use. }\end{array}$} & $\begin{array}{l}\text { (1) Use of photovoltaic generation and solar } \\
\text { thermal }\end{array}$ \\
\hline & (2) Promotion of thermal energy use \\
\hline & (3) Promotion of sharing energy system \\
\hline \multirow[t]{4}{*}{$\begin{array}{l}\text { 5. Reduction of } \mathrm{CO}_{2} \text { emission from buildings } \\
\text { Promotion of building rehabilitation to high } \\
\text { energy efficient building. }\end{array}$} & $\begin{array}{l}\text { (1) Promotion of building rehabilitation to high } \\
\text { energy efficient building at the reallocation of } \\
\text { old facilities to core area }\end{array}$ \\
\hline & $\begin{array}{l}\text { (2) Promotion of old building rehabilitation to high } \\
\text { energy efficient building }\end{array}$ \\
\hline & $\begin{array}{l}\text { (3) Promotion of old housing rehabilitation to high } \\
\text { energy efficient housing }\end{array}$ \\
\hline & $\begin{array}{l}\text { (4) Introduction of high energy efficient building } \\
\text { services }\end{array}$ \\
\hline \multirow{3}{*}{$\begin{array}{l}\text { 6. Reduction of } \mathrm{CO}_{2} \text { emissions from vehicle } \\
\text { Promotion of eco car like electric vehicle. }\end{array}$} & (1) Promotion of eco car use \\
\hline & (2) Installation of rapid charger station \\
\hline & (3) Introduction of personal vehicle use \\
\hline
\end{tabular}

Table 4: Cases of urban functions centralization.

\begin{tabular}{|c|c|c|c|}
\hline \multirow{2}{*}{\multicolumn{2}{|c|}{$\begin{array}{l}\text { Patterns of } \\
\text { centralization }\end{array}$}} & \multicolumn{2}{|c|}{ Core area } \\
\hline & & $\begin{array}{l}\text { Urban facilities (public facility, medical } \\
\text { and welfare institution, commercial } \\
\text { facility) }\end{array}$ & Residential functions \\
\hline \multicolumn{2}{|c|}{ Current situation } & No centralization & No centralization \\
\hline $\begin{array}{l}\text { Short- } \\
\text { term }\end{array}$ & Case (1) & $\begin{array}{l}\text { Urban facilities in municipal office } \\
\text { building area of ongoing rearrangement } \\
\text { plan }\end{array}$ & $\begin{array}{l}\text { Residential functions in municipal } \\
\text { office building area of ongoing } \\
\text { rearrangement plan }\end{array}$ \\
\hline \multirow{4}{*}{$\begin{array}{l}\text { Middle and } \\
\text { Long-term }\end{array}$} & Case (2) & $\begin{array}{l}\text { Old urban facilities* of outer part of core } \\
\text { area }\end{array}$ & - \\
\hline & Case (3) & Urban facilities of outer part of core area & - \\
\hline & Case (4) & $\begin{array}{l}\text { Old urban facilities* of outer part of core } \\
\text { area }\end{array}$ & $\begin{array}{l}\text { Old Residential functions * of } \\
\text { outer part of core area }\end{array}$ \\
\hline & Case (5) & Urban facilities of outer part of core area & $\begin{array}{l}\text { Residential functions * of outer } \\
\text { part of core area }\end{array}$ \\
\hline
\end{tabular}

*More than 30 years old. 


\subsection{Analysis method}

For detailed evaluation of centralized urban structure effects [6], it is important to evaluate building allocation, since centralization promotes reallocation of many facilities. In addition, since moving paths of the people are strongly related to location of facilities, traffic case studies are needed to be evaluated by the building units.

In this analysis, we utilized fix-asset-register [7]; official big data of all buildings which contain square measure by each function. We divided city area into detailed districts by GIS, and evaluate $\mathrm{CO}_{2}$ reduction effects which include consumer and transportation sectors. Detailed calculation methods are shown on table 5 .

Table 5: Calculation methods of $\mathrm{CO}_{2}$ reduction from consumer and transportation sector.

\begin{tabular}{|c|c|c|}
\hline \multirow[t]{2}{*}{$\begin{array}{l}\text { Consumer } \\
\text { Sector }\end{array}$} & $\begin{array}{l}\mathrm{CO}_{2} \text { reduction } \\
\text { calculation } \\
\text { methods }\end{array}$ & $\begin{array}{l}\mathrm{CO}_{2} \text { emission of consumer sector } \\
=\Sigma_{\text {(use) }} \text { (floor area according to use (office, school, } \\
\text { commerce, eating and drinking, meeting place, } \\
\text { hospital, hotel, door-built house, apartment complex) } \\
\left(\mathrm{m}^{2}\right) \\
\times \quad \text { emissions intensity according to floor use }\left(\mathrm{kg}^{-} \mathrm{CO}_{2} /\right. \\
\left.\mathrm{m}^{2}\right) \text { ) }\end{array}$ \\
\hline & $\begin{array}{l}\text { Logic of } \mathrm{CO}_{2} \\
\text { reduction }\end{array}$ & $\begin{array}{l}\text { - shift from detached houses to multiple dwellings reduce } \\
\mathrm{CO}_{2} \text { emission. } \\
\text { building renewal which installed low carbon technologies } \\
\text { reduce } \mathrm{CO}_{2} \text { emission. }\end{array}$ \\
\hline \multirow[t]{2}{*}{$\begin{array}{l}\text { Transportation } \\
\text { Sector [9] }\end{array}$} & $\begin{array}{l}\mathrm{CO}_{2} \text { reduction } \\
\text { calculation } \\
\text { methods }\end{array}$ & $\begin{array}{l}\mathrm{CO}_{2} \text { emission of transportation sector } \\
=\Sigma_{\text {(use, traffic mode) }} \text { (floor area according to use (office, } \\
\text { commerce, house, hospital) }\left(\mathrm{m}^{2}\right) \\
\times \quad \text { trip generation intensity according to floor use }(\mathrm{kg}- \\
\left.\mathrm{CO}_{2} / \mathrm{m}^{2}\right) \\
\times \quad \text { traffic modal split rate according to use (\%) } \\
\times \quad \text { travel distance (trip length) according to use, traffic } \\
\text { mode }(\mathrm{km}) \\
\times \quad \text { emissions intensity according to traffic mode }(\mathrm{kg}- \\
\left.\left.\mathrm{CO}_{2} / \mathrm{km}\right)\right)\end{array}$ \\
\hline & $\begin{array}{l}\text { Logic of } \mathrm{CO}_{2} \\
\text { reduction }\end{array}$ & $\begin{array}{l}\text { - modal shift from vehicle to public transportation reduce } \\
\mathrm{CO}_{2} \text { emission. } \\
\text { - shorten personal moving paths caused by centralization } \\
\text { reduce } \mathrm{CO}_{2} \text { emission. }\end{array}$ \\
\hline
\end{tabular}

\subsection{Result of analysis}

The results of impact analysis of centralization are shown in fig. 11. It was estimated that there were $1 \%$ of $\mathrm{CO}_{2}$ reduction effects in the case (1); municipal office building area redevelopment. There were $4 \%$ of $\mathrm{CO}_{2}$ reduction effects in the case (2); centralizing old urban facilities of outer part of core area, and that there were $11 \%$ of $\mathrm{CO}_{2}$ reduction effects in the case (3); centralizing all urban facilities of outer part of core area. Furthermore, in case (4); centralizing residential functions of more than 30 years old in addition to case (2), reduced 
$8 \%$, and in case (5); centralizing all residential functions in addition to case (3), reduced $19 \%$.

The breakdown of the $\mathrm{CO}_{2}$ reduction effects are shown in fig. 12. The breakdown of the effects is calculated by measures of the consumer sector; shifting from detached house to apartment complex and saving energy of buildings, and the transportation sector; reduction of vehicle sharing rate and length of the trip. When urban facilities and residential functions are gathered together like in case (4), (5), it became clear that there was an approximately equal reduction effect in the consumer sector and the transportation sector. From the above result, it is essential to promote measures by the both side of consumer sector and transportation sector.

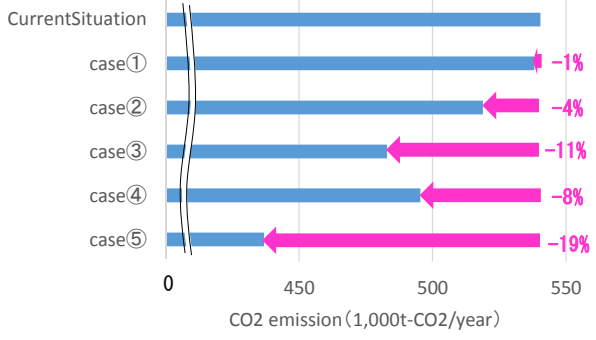

Figure 11: Effects of $\mathrm{CO}_{2}$ reduction.

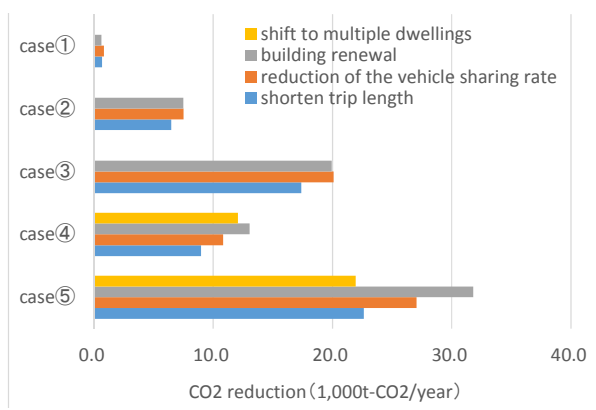

Figure 12: Breakdown of the effects.

\subsection{Conclusion and consideration of the study}

It should been noted that urban sustainability is improved by centralizing urban and residential functions. Our study found that centralization brings the effects of $\mathrm{CO}_{2}$ reduction. Moreover, rising population density in core area contribute to create vital community, and centralizing urban functions improves convenience of daily life. Figure 13 shows the population density in core area of case (4) and (5) in which residential functions are centralized. In case (4); over 30 years old housing are centralized, the population density in core area become 10,202 
people per $\mathrm{km}^{2}$. And in case (5); all residential functions are centralized in core area, the population density are calculated to 16,033 people per $\mathrm{km}^{2}$. For instance, one of big cities of Osaka, the population density of whole city of Osaka is 11,740 people per $\mathrm{km}^{2}$ [9]. The population density of case (4) and (5) are high enough compared to the population density in Osaka city.

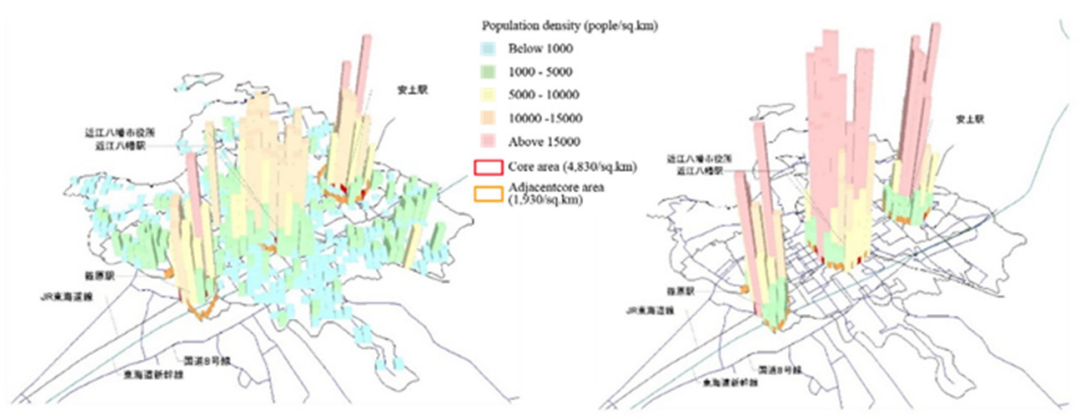

Notice: This is case study of night time population density.

Figure 13: Calculated population density in core area of case (4) and (5).

As shown in fig. 14, in core area, since unused floor area are still remaining, there are enough capacity to accumulate all floor area of existing housing in outer part of core area in Omihachiman. For realizing a sustainable city, it is essential to promote centralization of both urban and residential functions

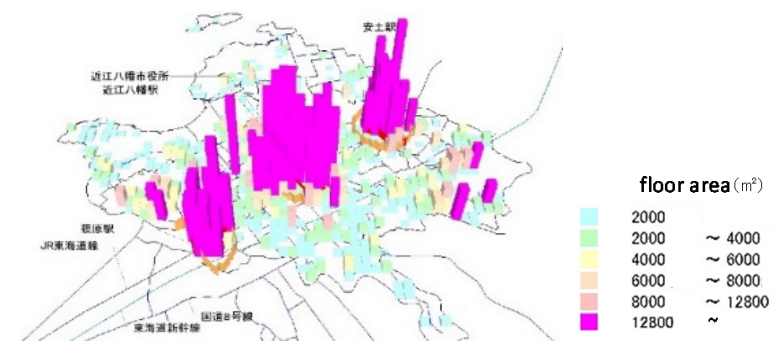

Figure 14: Assumed volume in core area in which residential functions are centralized in core area regarding to the present floor area ratio under Urban Planning Act.

In conclusion, the analytical method which unified the consumer sector and transportation sector was developed in effect analysis of each measure. We estimated effects of $\mathrm{CO}_{2}$ reduction of several patterns of centralization. As a result, this study found that centralization contributes to reduce $\mathrm{CO}_{2}$ emissions. Moreover, it clarified the differences of effects brought out from centralization patterns.

This result serves as very effective information in the scene of planning measures for a low-carbon city development at local government, or civic consensus building. 
Furthermore, when centralized urban structure is realized, it can be expected that the sustainability of a city will further increase. Its scale merit of centralized urban structure contributes to efficient energy use within community in which buildings are settled close each other. Also, bus route can be arranged for efficient operation.

Based on the results of this paper, by accumulating effects of various measures, we expect further progress toward meeting achievement of low-carbon urban development.

\section{References}

[1] Ministry of Environment, greenhouse effect gas emission data (definite value in the 2012 fiscal year), 2014.4.

[2] Cabinet Office, Government of Japan, white paper on aging society, 2014.

[3] Ministry of Land, Infrastructure, Transport and Tourism, Low Carbon City Promotion Act (pamphlet), 2014.5.

[4] Ministry of Land, Infrastructure, Transport and Tourism, Low Carbon City Development Guidance, December 2012.

[5] City of Omihachiman, Low Carbon City Development Plan for Omihachiman City, March 2014.

[6] Ministry of Land, Infrastructure, Transport and Tourism, Low Carbon City Development handbook, December 2013.

[7] City of Omihachiman, Basic register of residents, 2013.

[8] Keihanshin city zone transport planning conference, The 5th Kinki district person trip survey, 2010.

[9] City of Osaka, statistics of Osaka city, 2009. 